\title{
The impact of women consumers’ psychology and behavior on marketing strategies
}

\author{
Yanni $\mathrm{Li}^{1, \mathrm{a}}$, Zhijuan $\mathrm{Li}^{2}{ }^{2}$, Yiqun Liu ${ }^{1}$, and Yang Teng ${ }^{1}$ \\ ${ }^{1}$ School of Foreign Languages, Changchun Institute of Technology, Jilin 130012, China \\ ${ }^{2}$ School of Foreign Languages, Changchun University, Jilin 130022, China \\ aliyanni2007@163.com
}

Keywords: women; consume; psychology; marketing.

\begin{abstract}
Modern women are the combination of knowledge, intelligence, and ability. They are financially independent and pursue the fulfillment of self-value. . The paper mainly illustrates how modern marketers develop their marketing strategy in terms of the three important elements (product, price and communication) after their careful observation and scientific research on women consumers' psychology and behavior. In the guide of that information, marketers design the products which fully satisfy consumer's physical and emotional needs; set the suitable price that attract women, and then effectively communicate with women consumers to establish ongoing and trusting relationship. The paper tries to combine the marketing theory and case analysis to conclude that the research of customer will be the trend of commercial strategy in the extremely competitive market.
\end{abstract}

\section{Introduction}

A Nowadays, description of women and men are common in all the media coverage, radio, press, television, movies, and gender-related topics frequently make the headline and form the central focus for program. It is virtually impossible to pick up a magazine or newspaper without finding out at least one article describing women's changing social status, attitudes, lifestyle, and behavior with respect to their traditional household role. More and more women are financially independent.

\section{Reasons of marketing to women}

Modern women's multi-roles in society enable them to have the following four components of women's market:

Firstly, modern women have strong earning power. Their purses are great temptation for marketers and advertisers. From a small size manufacture factory's workplace to a big and luxurious chief executive officer's office, from a small kindergarten's classroom to the stage in a famous university's lecture, from a neighborhood committee's office to an international conference, women are showing themselves anywhere and anytime. The high paid occupation and leading position are not men's privilege any more. It is fairly normal for women to earn much more salary than men had. Therefore, it is also fairly normal for marketers to switch their attention to modern women's purses.

Secondly, modern women consumers' spending power is also appealing. Women are still the household chief purchasing officers. Although they represent only half of the total consumer market, women's multi-roles enable them to make the vast majority of purchasing decision. Furthermore, when it comes to big purchase like household appliances, cars, houses, it seems that it is often the men that make the decision, but if the housewife is not in favor of the product, it can also seldom make the deal. A marketer once said: "Women are the largest single spending bloc on the planet," As he sees it, "It is just stupid not to cater to them."

Last but not least, modern women have high demand and desire. Women have strong desires for all the beautiful things. They never felt enough about their overflowed closets, hundreds of pairs of shoes, countless decorations, various hairstyle and functional make-up cosmetics.

Modern women are indeed an extremely powerful and appealing sector of consumers. It is time for business people to recognize that women consumers are a powerful force that cannot be overlooked. 
If businesses are interested in growing to new height of success, he or she should get a strategy to make sure "you have got women". Big international corporations which operate business on a global scale have begun to realize that women's economic power is no doubt going to affect their large share in market and spend more efforts on the research of women consumers' psychology and behavior, in order to make the product perfect “fit for her". However, it is not easy to gain women's satisfaction and preference if the marketers still hold their old stereotypical type about women only as housewife and do not have the subject-by-subject overview of women's attitude, behavior, consumer preference and so forth. Many companies still consider women as "minority" or niche consumers. Such "minority think" can cripple any significant change toward women consumers because it does not place women in their rightful place as majority consumers whose wants and needs are critical to marketing strategy.

\section{Consumer-focused products.}

A product is anything a consumer acquires or might acquire to meet a perceived need. Consumers are generally buying need satisfaction, not physical product attributes [1]. Consumers do not buy products; instead, they buy motive satisfaction or problem solution. For example, women consumers do not buy perfume or milk lotion (or a chemical compound with certain odoriferous characteristics): instead, they buy romance, appeal, sex, sensual pleasure, sophistication, and a host of emotional and psychological benefits. Women consumers do not actually buy expensive jewelry because of its preciousness, but it is a sign for elegance, financial affluence and marriage happiness. Just like the former head of Revlon said: "in the factory we make cosmetics, in the store we sell hope."

More and more women today regard shopping as their major leisure and lifestyle activity. The large stores and supermarkets are also trying to place more product categories for women's free selection and choice. Women are always ready to pay for the product that attract their eyes and satisfy their needs.

\subsection{Products for women's need.}

It is crucial for marketer to bear in mind what is women's value, what women cherish, what they take pride in, what they care, what they enjoy, and understand their women consumers' way of knowing---sense and sensitivity, compared with the mind of men---things and theorems. Only with the help of women's research, can the product--designer make the real product "perfectly fit for her". Webster in 1997 said:" the successful organization of the future will be customer-focused, not product or technology focused, supplied by a market information competence that links the voice of customer to all the firm's value delivery process...Successful marketing organizations will have the skills necessary to manage multiple strategic marketing processes, yet many of which have not, until recently, been regarded as within the domain of marketing."

\subsection{Products for women consumers' changeable market.}

If a product is determined to win consumers' money, there should be a concern for the dynamic change of the marketing environment. Marketing environment can be divided into the competitive environment (including the company, its immediate competitor and customers) and the macro-environment (the wider social political and economic setting in which organization operates). Of central importance in developing and implanting a robust marketing strategy is awareness of how the environment in which marketing takes place is changing.

In a word, women's self-regard attitude is likely to be an ongoing, dynamic process. The change will create more needs and demand between women consumers, which in turn will provide more opportunities for business which have the insight to changing environments.

\subsection{Products for different women market segments.}

We cannot expect a piece of product or advertising commercials to work for all women. Neither the women's nor the men's market is as homogenous as once it was. Women fulfill a multitude of roles today and have a wide range of attitudes about their roles in society, and women varies and differ from each other according to their value concept, age, degree of education, income, profession, even the cultural background. Just try to illustrate from the aspect of age, we can learn that middle-aged 
women above 40 who are married tend to put much emphasis on their family and much of their spending is for their children. However, the young girls between 21 to 32 whom often have less financial pressure and family burden tend to spend all the money they earned. They usually have little limitation and control on their spending. Therefore, the different consuming groups need different products to satisfy their needs. That is when the marketing segmentation came up.

According to Del I. Hawkins' segmentation of women in America; at least four significant female market segments exist [2]:

(1) Traditional housewife: Generally married; prefers to stay at home. Very home-and—family centered. They Desire to please husband andlor children. They Seek satisfaction meaning from household and family maintenances and Feel supported by family and is generally content with role.

(2) Trapped housewife: Generally married. They would prefer to work, but stays at home due to young children, lack of outside opportunities, or family pressure. Does not enjoy mist household chores. Has mixed feelings about current status and is concerned about lost opportunities.

(3) Trapped working woman: Married or single. They would prefer to stay at home, but works for economic necessity or social or family pressure. Does not derive satisfaction or meaning from employment. Enjoys most household activities, but is frustrated by lack of time. Feel conflict about her role, particularly if younger children at home.

(4) Career working woman. Married or single. They prefer to work and Derive satisfaction and meaning from employment rather than or in addition to, home and family. They Experience some conflict over her role if younger children are at home, but are generally content. They Views home maintenance as a necessary evil and feel pressed for time.

Each woman has her own attitude and personality. It is crucial to decide which segment you are ready to target and then "treat" each segment differently.

\section{Marketing strategies toward women}

\subsection{Lower price that attracts women}

Women are sensitive about the price, which can explain why some marketers often promote their sale in the activity of "on sale". The attractive bulletin printed the lower price often push women consumers to buy something which they actually do not need or cannot consume for a long time. For example, a cluster of masks which is nearly to its validity of time at its surprised price will make women grab and then put the masks into their shopping cart; even they can use one piece of the mask back home. A pair of shoes which somewhat cause the pain of ankle after long walking due to its poor quality often are bought by a lady just because the shoes' beautiful design and really low price. In fact, she wears the shoes only once after she owns it because the discomfort in ankle makes her put the shoes in her closet to appreciate. It is the temptation of "lower price", and we often called this behavior "impulse buying". Women prefer to do "impulse buying" than men because men often care less about the price but the product's function and utility. Nearly all the women have the experience of impulse buying for any product ranged from clothes to food, cosmetics to household appliance just by the guise of the attractiveness of "really-super-lower-price" That is why we say, "Despite women angry or happy, store always is the beneficiary"[3].

\subsection{Higher price that means quality}

As the growth of living standard, most women consumers tend to put much emphasis on the quality and functions today. A less decrease in the price can seldom make them rush for the items. In contrast, the campaign of preferential benefit sometimes probably has negative effects on the brand image and further value promotion. Many products which seldom use the price strategy seem to like to cause women's preference because those were regarded as having long--term reputation and high standard quality.

In a word, relying on lower price strategy to promote sale is far from building a loyalty to a brand. Maybe it can increase the sale in a short period, but it is just a "false loyalty" which backed up by low price [4]. The firm should set a really attractive repayment and pricing policy based on different women consumers' segments and their related psychology and price value. 


\subsection{Strategic Communications with women consumers}

Marketing communication includes advertising, the sale force, public relations, packaging, and any other signals that the firm provides about itself and its products. An effective communication strategy target at women consumers requires answers to the following question: What effects do we want our communication to have on the target audience? We often state that the purpose of advertising and some marketing communication is to promote sale. While, this is the ultimate objective, the behavior objective is often much more immediate, that is, it may seek to have the audience learn something about the product, seek more information about it ,then like the product and recommend it to others, feel good about having bought the product, or a host of other communication effects.

Word — of - mouth communications, individual sharing information with other individuals, are a critical influence on consumer decision and business success. We learn about new products, restaurants, and retail outlets from our friends and other reference group" (1) by observing or participating with them as they use products and services, or by (2) seeking or receiving advice and information from them. About half of consumers agree that they "often seek advice of others before making a decision to buy products or services, and 40percent feel that people often come to them for Purchase advice.

\section{Summary}

In the extremely competitive marketplace, marketers wish they could get inside the consumer's heads as well as their wallets. "Some business live on a razor thin margin, and it is really tough to survive in the market.” said Dr Leigh McAlister, marketing professor at the university of Texas at Austin [5]. Therefore, Diving finicky shoppers' needs and wants and then designing effective marketing strategy toward the target market are the key to winning customers. Discerning what the consumer desires is important, in fact, the study of consumer behavior and psychology has become as crucial as the analysis of profit margin and gross sales. Although humans can be fickle creatures, certain general behavior patterns seem to emerge when people set out to shop. In conclusion, the emergence of consumer psychology will provide more creative ideas for the further progress of marketing, and the research of the psychological science will have a lot of knowledge to be explored as the development of the commercial activities.

\section{References}

[1]. Graham Hooley, John Saunders Nigel. Marketing Strategy and Competitive Position (third edition). Zhongxin Press, 2004, p34-35.

[2]. Del I. Hawkins. Consumer Behavior. Mechanic Industry Press, 2006, 8, p.10-11.

[3]. Wanzhen Wang. On Women's Psychology of Consumption in Marketing. Fujian Administration College, 2005, 11, p25-26

[4]. Man Wang. “She-era” Business Need to See Her World. Business Forum, 2004, 9, p 3.

[5]. Ross Brennan, Paul Baines and Paul Garneau. Contemporary Strategic Marketing. Great Britain: Antony Rowe Ltd, 2006, 2 p10-11. 